\title{
South East Queensland: Change and continuity in planning
}

Paul Burton

\section{Introduction}

Of all the metropolitan regions of Australia, South East Queensland (SEQ) is the most paradoxical. On the one hand it is presented as something of an exception, not simply because its very name avoids reference to the capital city at its core but because it reflects also the fact that Brisbane as the state capital is less dominant than in other states and territories, accommodating less than half of the state's population (Burton, 2010; Gleeson and Steele, 2010). On the other hand, as one of the fastest growing regions in Australia for much of the last half century, it is seen to epitomise the challenges facing metropolitan regions in general and to serve as a test bed for urban planning and growth management policies (Savery, 2010). As Gleeson and Steele also note, this corner of Queensland has come to be seen as an 'increasingly important crucible of change that captures and reflects many of the growth management dilemmas and opportunities facing the Australian settlement system ... at the metropolitan level' (Gleeson and Steele, 2010, p14).

With people drawn from elsewhere in Australia and indeed the rest of the world by its congenial climate, the proximity of beaches and other high quality environmental attractions and by a variety of campaigns promoting these and other benefits, the scale and pace of this population growth has presented substantial challenges to planners and politicians. In trying to ensure that employment opportunities are available to the newcomers, that public services and infrastructure keep pace with population growth and that the environmental attractions of the region are not substantially damaged in the process of growth, plans for the region must deal with conflicting pressures and expectations. The regional plans and strategies produced over the last decades have been recognised in many quarters for their strategic and integrated approaches to growth management (Margerum, 2002; Abbott, 2009; Gleeson et al., 2012) but as growth continues and new social, economic and environmental pressures emerge so do the challenges associated with developing and implementing effective regional plans. While focusing on metropolitan and regional planning in SEQ over the last sixteen years, this chapter considers also how planning at this scale might develop in the coming years.

This chapter is presented in four main sections. It begins by describing briefly the growth of SEQ since 2000 before charting chronologically the various attempts since the beginning of this century to meet the challenges of growth management through processes of metropolitan and regional planning. It goes on to identify the critical features of these plans and to offer a critical assessment of their success and failures. The concluding section focusses on the political and institutional pressures and problems associated with developing collaborative arrangements between state and local governments and considers the consequences of a shifting balance of power and responsibility between these levels over the last sixteen years.

\section{Growth and change since 2000}

Since 2000 the region has continued to follow a similar pattern to its growth over the preceding decades. In the first decade of the new century, it grew by approximately 700,000 people to reach 3.18 million at an average annual growth rate of 2.5 per cent, consistent with 
the average annual growth rate since 1980. The coastal cities of Brisbane, the Gold Coast and the Sunshine Coast remained the focal points of population growth within the region, while the more western settlements of Ipswich, Toowoomba and Beaudesert experienced more modest increases in total population. Patterns of growth within these major urban areas and cities were also varied and typically clustered around particular nodes. Brisbane, for example, saw growth concentrated within its inner, middle and outer suburban edge areas, while the outermost areas (around 50km from the centre) remained stable or even declined in the decade to 2011 (Coffee et al., 2016). Within the City of Gold Coast growth has typically been greatest within its coastal strip on the eastern edge of the city, but significant concentrations of new housing continue to be developed west of the Pacific Motorway in the north of the city. A similar pattern is seen in the Sunshine Coast, where growth has been concentrated in coastal regions of Maroochydore and Caloundra with little significant population growth in the inland and western regions.

\section{Insert Map One about here}

Much of the population growth of SEQ is the product of inter-state and international migration, driven by the pursuit of an attractive lifestyle. Writing about the sustained growth of the Gold Coast, Bernard Salt $(2015$, p.6) has spoken of the city being 'willed into existence because of the fundamental demand for leisure and lifestyle'. While this partly reflects the hyperbole of popular demography, it captures a widely held view that the growth of the whole region has continued to be built upon factors not directly associated with economic growth, but with more nebulous lifestyle attractions (Guhathakurta \& Stimson, 2007). In other words, the initial decision to move to SEQ often reflects a desire for an attractive lifestyle, while more specific locational decisions take additional account of the accessibility of the dominant labour market of Brisbane.

The components of this growing population reflect a combination of net overseas migration, net interstate migration and a slightly positive rate of natural increase. Net overseas migration into Queensland has always been a function of the national profile, with the state typically receiving a share of migrants commensurate with its share of the total population of Australia. However, net overseas migration to Australia has varied considerably over the years, ranging from low points of around 20,000 per annum in the mid-1970s and mid-1990s, to around 300,000 by the late 2000 s. These variations are primarily policy-driven and reflect changing attitudes to the need for key workers, family reunification and the obligations of humanitarian settlement. Net interstate migration has also fluctuated considerably, although in the last two decades of the $20^{\text {th }}$ century there was an average annual net gain of 30,000 people moving to Queensland from interstate. Fertility and mortality rates across the state have also changed, but are much less volatile, leading to a rate of natural increase that continues to rise slowly but surely and which currently accounts for over half of the total population growth of the state (Queensland Government Statistician's Office, 2016). Bell et al., (2010) have explored possible population futures for SEQ, including the consequences of setting population targets or caps in the name of sustainable development. They conclude that, in order to limit overall growth to 2010 levels, almost 10,000 people per annum would be required to leave the region, simply to offset the rate of natural increase. 
Recent population data reveal some interesting new developments that would not have been part of the assumptions that underpinned previous metropolitan plans and appear to have had only a marginal impact on the latest draft strategy. While neither the continued growth of the state's population nor the relatively slow rate of growth is surprising, the increasing significance of natural increase as the driver of growth is noteworthy. While net interstate migration remains positive, the impact of overseas migration is of greater significance as these migrants typically have a younger age profile and as such are serving to slow the overall ageing of the population. In other words, much of the population growth of SEQ and some of its major cities such as the Gold Coast has in the past been due to the interstate migration of older people, accelerating the ageing of the total population, whereas the growing significance of younger, international migrants has slowed this process.

Of course, the ageing of the population as a whole continues and in the future there may be social challenges in caring for an increasingly ethnically diverse population of older people as well as demand for new types of housing, different patterns of public services, especially in health and social care, and continuing pressures to preserve the environmental amenities that have been hallmarks of the attractiveness of the region.

State-wide trends are reflected also in the relationship between SEQ and the rest of the state. Annual growth in SEQ has outpaced the rest of the state over the past 20 years and 8 out of the 10 most populous local government areas are located in SEQ, with only 2 of the 10 , Townsville and Cairns, located outside the region. Following the end of the recent resources boom, migration to these centres of mining and processing in regional towns has declined while migration into the more diverse economies of SEQ cities continues.

\section{Chronology of plans}

\section{The $20^{\text {th }}$ century foundations of regional planning in SEQ}

Regional planning in Queensland and SEQ took firm hold in the early years of the $21^{\text {st }}$ century, but the foundations were laid in the latter years of the $20^{\text {th }}$ century. Queensland became exceptional in grasping the political nettle of enforcing local government amalgamation on its capital city in 1925, enabling the Greater Brisbane Council to play, in theory at least, a more prominent and proactive role in planning and managing the rapid growth of the city and served also to deflect for a time political pressures for the Queensland government to become more involved in planning for the wider region. By the 1970s, concern for regional scale planning in the south-east corner of the state saw the creation of the Moreton Regional Coordination Council (MRCC) with a remit to prepare a regional growth strategy for the area covered by Brisbane City and 16 surrounding municipalities. Although the MRCC was abolished in the mid-1970s in the face of a shared anti-planning disposition by Premier Joh Bjelke-Petersen and Prime Minister Malcolm Fraser, it continued to meet as the Moreton Regional Organisation of Councils (MROC), reflecting the recognition by all seventeen local authorities that some degree of planning and coordination among themselves was mutually beneficial.

By the 1990s this recognition had spread to the State Government, in particular through the support of Tom Burns, Local Government Minister in the newly elected Goss Labor Government. John Abbott (2012) describes this period as one of initial voluntary growth management, in which relations between the local governments of the region and the state 
government were reasonably cordial, but underlain by an underlying sense of suspicion, certainly on the part of the local councils.

While these arrangements were seen in a very positive light and indeed as something of a model outside of Queensland, within the state government itself tensions were emerging around the development and implementation of a number of related but more focussed plans. In particular a Regional Open Space System plan, designed to limit the loss of open space and manage the remaining stock more effectively, was subject to review in 1996 by the new Coalition government led by Premier Rob Borbidge and became a source of public concern, including to the Labor government of Peter Beattie, elected in 1998, around regional planning processes. Less visible to the public at large, but nonetheless significant in laying the foundation for a regional planning system, sectoral plans and strategies were prepared, covering transport, air quality, water, economic development and nature conservation. While each was valuable, there was minimal collaborative planning across these substantive areas, which typically reflected departmental silos within the state government. Despite considerable efforts by government officials to collaborate and coordinate their efforts, a plethora of only occasionally interconnected sectoral strategies emerged (James and Burton, 2016).

\section{From voluntary to statutory regional planning}

Following the re-election of the Beattie government in 2001 the process of strengthening the statutory basis of regional planning in SEQ gained momentum. A major evaluation of the economic performance of the region (DLGP, 2002) found some positive trends (strong residential and employment growth in Brisbane's CBD) and some negative (lack of employment growth in other designated growth areas), but the report's greatest significance lay in preparing the ground for what was to become the 2005 South East Queensland Regional Plan (SEQRP). While identifying areas and issues for new policy work, the report also flagged eight issues that were already deemed important, but which appeared to be struggling in their implementation. Most of these areas fell under the broad heading of environmental policy, including biodiversity conservation, coastal management, water and air quality, and water supply.

Part of this implementation problem lay in the relationship between regional plans and the local planning schemes prepared in accordance with Queensland's Integrated Planning Act introduced in 1997, through which regional objectives were ot be realised. The local governments of SEQ were struggling to prepare planning schemes that could effectively manage the consequences of rapid population growth in the absence of a statutory regional plan, while Planning Minister Nita Cunningham appeared to see the problem differently in suggesting that any sensible regional plan would be simply the sum of all local plans (Abbott, 2012, p.38).

At this point a disparate coalition of forces began to emerge to give public expression to the need for a new regional plan with more statutory power. The Queensland divisions of the Planning Institute of Australia and the Urban Development Institute of Australia and, importantly, the local media began to campaign for change, alongside the Brisbane Institute under the leadership of urban historian Peter Spearritt. The challenge was taken up by South East Queensland Regional Organisation of Councils which, following a summit of SEQ mayors held at the end of 2003, agreed to press for a new statutory approach to regional 
planning. This was in turn accepted by the Beattie government, re-elected in February 2004, and led by Minister Mackenroth from his position as chair of the SEQ Regional Coordination Committee. This planning process was overseen by yet another state-level committee, the Urban Management and Infrastructure Coordination Committee (UMICC), which recommended the creation of an Office of Urban Management (OUM) to lead regional planning in SEQ.

Among the more significant responsibilities of the OUM, which was established in March 2004, were the inclusion of open space and landscape planning into the statutory framework and the preparation of regional infrastructure plans as part of the annual budget process. The Executive Director of the OUM, Michael Kerry, seconded from his role as head of Urban Management at Brisbane City Council, set about preparing a draft SEQRP for public consultation by October 2004. This proved to be a relatively popular process, by the standards of regional planning consultation, with over 8,000 formal submissions following 13 public meetings and an extensive advertising campaign in the local media.

The SEQRP, 2005-2026

The SEQRP was published in June 2005 (OUM, 2005b) and received widespread support from the public, the development industry and from other levels of government.

This first statutory SEQRP was designed primarily to manage anticipated population growth and its consequences over a 20 year period, trying to reconcile the benefits of growth with a desire to protect the quality of life. It was prepared under the auspices of an amended Integrated Planning Act, 1997 which obliged a degree of public consultation over draft proposals and, during plan preparation, with the Regional Consultative Committee, first established in 1994 as a joint venture between the state and local governments. The SEQRP for the first time had the weight of being a State planning instrument and took precedence over all local planning policies and regulations. Planning schemes prepared by local authorities within the region were expected to be consistent with the SEQRP and those already in existence had to be amended within a reasonable period if they were not..

\section{Insert Map Two about here}

The main elements of what was essentially an indicative spatial plan included the identification of suitable land for future development to accommodate a growing population, the provision of infrastructure to service this population, a preference for more compact urban forms through urban infill and a limited number of new major development areas, diversification of the regional economy and the protection of natural environments and biodiversity. Of course, some of these elements were in conflict, not least in the desire to identify suitable greenfield land for new housing while at the same time trying to protect native vegetation and maintain biodiversity. One of the most visible and significant components of the new plan was the definition of an 'urban footprint' with statutory effect that sought to limit the location of major new development.

The desire for a more compact urban form has been a feature of all the strategic plans for SEQ, but its definition has typically lacked precision (Searle, 2010). Spencer et al. 's (2015) comparative analysis of population density in Australia's three largest cities reveals that in 
Brisbane, while 89 per cent of the population live within parts of the city that might be called 'urban' with a gross density of four or more people per hectare, this is limited to only 6 per cent of the total land area of the city (compared to, say, London where $99 \%$ of the population live in urban areas, which cover 80 per cent of the city). In other words, there appears to be considerable scope to increase densities to achieve a more compact urban form and indeed the first SEQRP proposed that 50 per cent of new residential dwellings should be built within the existing urban footprint.

The SEQRP also anticipated the preparation of a number of other plans, including growth management strategies and structure plans relating to local government areas. Local Growth Management Strategies (LGMS) were to be produced by each of the (then) 18 local governments in the region to identify major development areas that would require subsequent structure planning. This process recognised that it would take some time for local planning schemes to be amended and brought into line with the SEQRP. The LGMS were expected to perform a dual and potentially conflicting role in reflecting the strategic intent of the SEQRP at the local level while, at the same time, identifying and assessing possible new major growth areas not yet reflected in the plan.

Just as previous voluntary regional planning frameworks had struggled in some areas with implementation, so the governance arrangements associated with the new statutory SEQRP were criticised for failing to clarify problematic relationships between State and local government planning policies (Ireland, 2006). In particular, there remained some ongoing lack of clarity about the incorporation of local structure plans into amended versions of the SEQRP. This proved an especially difficult political challenge as it exposed different stances between some local councils and the State in the location of emerging and potential new growth areas. These tensions often played out in the regional leadership forums established in the years leading up to the publication of the first SEQRP. While important preparatory work had been carried out by SEQROC, in late 2005 this body was reformed into the Council of Mayors SEQ (COMSEQ) under the leadership of Campbell Newman, Liberal Mayor of the City of Brisbane who came to office in 2004. While the focus of COMSEQ was more on the implementation of what was in the first version of the SEQRP rather than on getting new elements included, its capacity to manage conflicting local views on growth location remained limited.

Because of the imperative to avoid delays in publishing the first draft of the SEQRP, a number of 'pipeline' growth areas were already under consideration but not able to be included. Hence, the plan was subject to almost immediate review through an investigation of the development potential of what was known as the Mt Lindsay/North Beaudesert Study Area. This was formalised as Amendment 1 and came in to effect in September 2006, identifying major activity centres at Flagstone, Yarrabilba, Jimboomba and Park Ridge. This illustrates that while there was concern with implementation of the plan, its content remained subject to constant pressure for revision from the outset, which in turn complicated the already complex processes of implementation. Another significant complicating factor in the implementation of the plan was the relationship of its spatial components with the planning of infrastructure investment.

The SEQ Infrastructure Plan and Program, 2005-2026 
One of the distinctive and valued aspects of the first statutory regional plan for SEQ was the Infrastructure Plan and Program (SEQIPP) that accompanied it. In their foreword, Premier Beattie and Deputy Premier Mackenroth pointed out that 'for the first time in history, the Queensland government is making a ten year commitment to fund the necessary infrastructure that supports growth in SEQ'. This ten year investment commitment was indeed novel as most forward commitments extended no further than four years and previous attempts at regional planning in Queensland had been bedevilled by a persistent failure to integrate infrastructure and regional planning processes (Minnery and Low Choy, 2010). As both the SEQRP and the SEQIPP were prepared by the Office of Urban Management, there was initial optimism that a degree of integration would be achieved in practice and indeed the SEQIPP was designed to show where a variety of critical state infrastructure investment was planned to support the spatial planning ambitions expressed in the SEQRP While some criticised this 'infrastructure turn' for its apparent subordination of spatial planning to project-based investment planning (Dodson, 2009; Gleeson and Steele, 2009), in SEQ the more pertinent criticism has been that the various iterations of the SEQIPP have not, in the face of financial dependency on Federal partners and the impact of the global financial crises, delivered all the promised infrastructure (Regan and Bajracharya, 2010).

\section{The SEQRP, 2009-2031}

By 2008 many of the growth management issues that lay at the heart of the 2005 plan were not only continuing, but becoming ever more pressing. High population growth, housing unaffordability, transport congestion and the need for employment generation persisted, but were joined by a new recognition that the impacts of climate change would exacerbate all these problems. A new Draft SEQRP 2009-31 was published for public consultation in December 2008 and a final version prepared in the light of submissions and in consultation with the RCC, coming into effect in July 2009. This new plan (DIP, 2009a) set out a number of new and emphatic strategic directions. Perhaps the most significant new emphasis was given to the impacts of climate change and oil vulnerability. The plan spoke of the need to mitigate climate change by reducing greenhouse gas emissions and to adapt to unavoidable impacts by protecting areas at risk, in particular from sea level rise. It also recognised the State's increasing vulnerability to rising oil prices and the consequential desire to reduce car dependency through a more compact urban form, although Queensland's Department of Transport and Main Roads' analysis of travel in SEQ between 1992 and 2009 showed that despite this policy objective, private car use remained fairly constant at around 80 per cent for all trips (DTMR, 2012). Greater emphasis was also given to protecting the regional landscape and biodiversity as well as supporting rural production. The overall strategic vision for the region was one of inter-connected communities that were more self-contained in terms of services and employment than in the past and which, therefore, would generate less demand for travel in private vehicles between residential and employment centres.

\section{Insert Map Three about here}

The new plan was not prepared not by the OUM, which had been abolished in April 2008, but by the new Department of Infrastructure and Planning (DIP), and a related SEQIPP for 
the period 2009-2026 was published alongside this new SEQRP. While departmental reorganisations are nothing new in state or federal governments, the abolition of the OUM was seen to have led to a loss of focus on integrated regional planning within the Queensland State Government and to a weakening of productive relations with other sectors, including the development industry and community representatives (Abbott, 2012, p.54).

The period since the adoption of the 2009 SEQRP has been one of considerable political change, with the Bligh Labor government replaced by the Newman Liberal-National Party Government in March 2012, which was replaced in turn by the Palaszczuk Labor Government in February 2015. Nevertheless, regional planning continued both in practice and as a process of monitoring, evaluation and review. In March 2010 a Growth Management Summit was held to consider, yet again, the challenges of planning for a rapidly growing population in SEQ and to propose any new priorities for future iterations of the SEQRP. One consequence of the Summit was the establishment of the SEQ Growth Management Program (SEQGMP), designed to 'inform and help prioritise state and local government planning actions and infrastructure investment' (Department of Local Government and Planning, 2010, p.2). Intended to deliver annual progress reports, the SEQGMP was concerned principally with availability of land for housing and industrial development and aimed to ensure a minimum of 10 years planned supply within local planning schemes and any relevant state government plans.

The election of the Newman Government saw a pronounced shift in emphasis from earlier periods and earlier versions of the SEQRP, even though Newman as Lord Mayor of Brisbane had endorsed both the 2005 and 2009 versions. As Premier he brought a renewed focus on the stimulation of economic growth and a commitment to reduce what he often described as growth-stunting green and red tape regulatory burdens (see, for example, Newman, 2012). This manifested itself most vividly in a series of battles with the Federal Government over its use of the Environment Protection and Biodiversity Conservation Act, 1999 to review and block a number of major project proposals in Queensland. But at the same time, the Newman Government embarked on the preparation of an ambitious plan for the whole of the state. Following what was described as 'the largest state-wide community engagement activity of its kind ever undertaken in Queensland, with more than 80000 people contributing to the process' (Queensland Government, 2014), the Queensland Plan was published in 2014, setting out a comprehensive array of policies and programs for all aspects of future growth. It included policies on environmental protection, infrastructure investment and regional development but, perhaps in recognition of criticism that state governments tended to be Brisbane-centric, it emphasised the importance of supporting population and economic growth outside SEQ, especially in the cities of north Queensland. The election of a new government only one year later meant the Queensland Plan had little time to serve as the foundation for more detailed planning or indeed for the re-shaping of the 2009 SEQRP. The Palaszczuk Labor Government elected in 2015 made a commitment to review many policy commitments and a review of the SEQRP was announced before the end of its first year in office.

2016 Draft SEQRP: Shaping SEQ 
The motivations and ambitions of the latest SEQRP, released in draft form in late 2016 (DILGP, 2016b), are very familiar: the population of SEQ is expected to continue to grow by approximately 2 million over the next 25 years if current trends continue and the consequences of this growth must be managed sensibly and sustainably. The plan aims to capitalise on the region's climatic location in making SEQ 'a world leading model of subtropical living' and in her introduction to the draft plan, Deputy Premier Jackie Trad (who at the time was both Minister for Infrastructure, Local Government and Planning and also Minister for Trade and Investment) set great store in the breadth and depth of community consultation that went into its preparation and on its focus on those issues that the community at large said were important. These included affordable housing, protection of the natural environment and the unique lifestyle offered by living in the region. In emphasising the importance of basing the plan on an extensive program of consultation, especially with the local councils and their mayors, the Deputy Premier is maintaining a tradition of engagement while making a claim to be doing it better than ever before.

\section{Insert Brisbane Tropical Living photo about here}

While a 50 year vision for the region is offered in response to a set of so-called mega-trends (Hajkowicz et al., 2012) the plan itself focuses only on the next 25 years and, if past practice is repeated, will be reviewed in 5-6 years' time. As with previous plans, the delivery of many of the plan's objectives will be achieved (or not) through the development and implementation of local planning schemes and the action of other state government departments and agencies, such as Economic Development Queensland and the office of the Queensland Government Architect.

\section{Insert Map Four about here}

In consultation events held around the region, officials from the Department of Infrastructure, Local Government and Planning (DILGP) - established in 2015 by the Palaszczuk Labor government- have set out the key elements of the plan and what distinguishes it from its predecessors. The principal element is the expansion of the urban footprint by 21,800 hectares, which includes 13,600 hectares of land over and above the 2009 plan and 8,200 hectares of 'new future urban land'. One major new development area is proposed at Beerwah East and 11 future growth areas are identified throughout the region. The plan provides indicative net residential densities for some of its regional activity centres, including 150-500 dwellings per hectare in capital city and principal regional activity centres such as Beenleigh, Southport and Toowoomba and 80-200 dwellings per hectare in major activity centres such as Coolangatta, Noosa and Yarrabilba. Density guidelines at smaller spatial scales and in other areas are to be determined by local governments through their local planning processes.

Insert Yarrabilba Street Scene photo about here 
The plan also presents a greater set of major aspirations including:

- Building a globally competitive regional economy by identifying and facilitating areas of high value and export-oriented business;

- Focusing more development in existing urban areas to accommodate SEQ's projected population and employment growth;

- Placing greater emphasis on public and active transport to move people around the region;

- Maximising the use of existing facilities before building new infrastructure, and identifying new 'region-shaping' infrastructure only where needed to increase accessibility and productivity to support the settlement pattern and economic policies;

- Increasing emphasis on protecting and sustainably using SEQ's regional landscapes and natural assets; and

- Identifying and mapping regional biodiversity corridors and values to support the protection of these values.

While there is much continuity between the current draft and previous plans, there are also some significant differences, including:

- Using employment planning benchmarks to ensure land and infrastructure are planned for and delivered locally to meet growth projections;

- Explicitly valuing good design, through the work of the Queensland Government Architect Queensland and the Urban Design and Places Panel, as a way to create more housing choice, and memorable and liveable urban places and spaces, to benefit communities socially, economically and environmentally;

- Working in parallel with the State Infrastructure Plan to ensure a coordinated approach to ongoing infrastructure and service delivery;

- Developing a more sophisticated (although as yet unspecified) approach to determining urban land supply, as well as improving ways to monitor supply and development activity, and the plan's performance over time;

- Delivering the plan through specific actions, including in City Deal partnerships with the Australian Government and SEQ local governments.

The draft plan claims to be more clear and concise than its predecessors and to provide a greater emphasis on delivery and implementation. This remains to be seen, but the public reception has so far been positive and even within the development industry there appears to be cautious optimism. The consultation period on the draft plan closes in March 2017 ahead of a further round of community conversations as well as preliminary analysis of submissions.

\section{Distinctive features, achievements and criticisms of SEQ metropolitan plans and strategies}


Over the last two decades, the plans, both voluntary and statutory, for SEQ have shown a high degree of consistency in their main aims and objectives and indeed these are not dissimilar to those expressed in the regional planning strategies of the other major cities (Hamnett and Freestone, 2016). The principal aim is to manage the consequences of anticipated population growth, rapid or otherwise, by identifying areas where that growth might be best accommodated. The second is to prepare the ground for economic development and job growth to employ this growing population. The third is to ensure that if these two forms of growth do not occur in broadly the same areas, then they are at least well connected through improved infrastructure for public and private transport. Finally, this transport infrastructure has also to connect other public service infrastructure such as schools, universities and hospitals. The achievement of these aims requires some degree of balance between different and competing pressures and imperatives, such as the promotion of population and economic growth and the protection and conservation of biodiversity, wildlife habitats and ecosystems in general. This is reflected in choices and tensions between accommodating growth through infill or through new development on so-called 'greenfield' sites along with an assumption that infill will typically be at higher densities than greenfield development, but might be easier to service with new or expanded infrastructure systems. One final common thread to the various SEQ regional plans and strategies lies in an enduring concern with their implementation; this is not to say that implementation has always been successful, rather that an explicit concern with implementation has persisted over the years and across various strategies. Each of the major planning aims described above is elaborated below.

\section{Growth areas and urban footprints}

Each of the regional plans has attempted to manage growth by restricting it to certain designated areas, typically the existing built up areas around the major cities but also in a number of smaller growth centres in more rural areas. The definition of these growth boundaries draws on information contained in the State Government's Digital Cadastral Database and provides a more precise delineation than previously. This delineation has considerable political and economic significance as it helps determine the development potential and hence the value of land. While the certainty provided by such boundaries is broadly welcomed, the limitations this imposes on development outside the footprint is subject to constant criticism from the development sector and its political representatives (eg Vit, 2016). Although these boundaries are supposed to reflect a supply of land sufficient to meet the need for new housing over the coming decades, this calculation is itself subject to constant challenge in the face of changing expectations of house and lot sizes, the acceptance of higher density development and the enduring problem of assembling land in fragmented ownership. The latest plan proposes a new balance in the assessment of areas of growth potential and future land supply, with a shift in favour of more infill development within the urban footprint.

\section{Insert Brisbane medium density infill photo about here}

This represents a long term trend, with the 2005 plan proposing an infill target of 40 per cent, the 2009 plan a 50 per cent target and the current plan a 60 per cent target. While these are 
relatively modest in comparison with other state targets, many in the Queensland development industry remain sceptical about their achievement, pointing to the lack of large parcels of land, the often high costs of site assembly and higher construction costs, all of which it predicts will lead to higher prices for new developments and an ongoing problem of housing affordability.

\section{Economic development as the foundation for growth}

Regional plans produced under the auspices of state governments led by different political parties have typically placed more or less emphasis on the fundamental need to stimulate economic growth as well as accommodating population growth. The new draft new plan proposes new employment planning benchmarks, but these appear to simply take sectoral estimates of job growth produced by the Treasury and allocate them formulaically to local governments in the region. Thus the City of Gold Coast is expected to identify sufficient land to accommodate precisely 433,432 new jobs in the period to 2041, although it is not clear what assumptions these estimates make about the relationship between economic growth and job growth in the light of anticipated but unspecified technological changes. To be sure, the current plan also identifies areas where new growth might be based on the proximity of $R \& D$ functions in a number of 'knowledge precincts' and is committed to promoting better connections between residential and employment areas. Nevertheless, the plan remains unavoidably focussed on the spatial distribution of economic growth rather than being a detailed prospectus for generating that growth.

\section{Connectivity through transport infrastructure}

Improved connectivity is, rightly, seen as one of the most significant ways in which growth can be managed in a sustainable way and the lifestyle attractions of the region preserved or even enhanced. One notable feature of the new plan is that it is not accompanied by a dedicated infrastructure plan. This was held to be one of the strengths of the previous two plans, but is considered unnecessary as the state now relies on one consolidated and integrated State Infrastructure Plan (DILGP, 2016a) which includes an analysis of the specific needs and opportunities within the SEQ region. While motorway upgrades and new rail services are planned, there is also a belief that urban consolidation and focused growth will over time reduce the considerable costs of congestion already experienced.

\section{Insert Gold Coast Transport investment photo about here}

\section{Keeping pace with public services}

In addition to large scale transport infrastructure in the form of roads and railways, tunnels and bridges, a growing population also needs community-based services such as schools and hospitals. The location of these facilities presents significant challenges for regional planners as low density, dispersed populations generate considerable traffic flows as residents typically travel to schools, hospitals and other health services by car. Within existing urban areas where challenging infill targets have been set in the latest SEQRP, finding the space for new schools, hospitals and other health care facilities is going to become increasingly difficult. 


\section{Growth and conservation}

The various plans for SEQ have always included a commitment to protecting and preserving native vegetation and ecosystems beyond and within the urban footprint and to conserving designated open space. While threats to the survival of flora and fauna in the region are becoming increasingly apparent, there is also growing recognition of the beneficial effects of greenspaces and vegetation within cities (Matthews et al., 2015). However, development pressures continue and the latest plan, like its predecessors, will no doubt struggle to strike a balance between growth and conservation that satisfies all parties.

\section{Implementation}

Although recognised by many as a series of laudable regional plans and strategies (Gleeson and Steele, 2010; Minnery and Low Choy, 2010) the various SEQ regional plans have also been subject to criticism, not least because of their failure to deliver their strategic visions in practice. The representative bodies of the development industry have, unsurprisingly, been among the staunchest critics. For example, the Property Council of Australia (PCA) has set out a series of criticisms and weaknesses of past SEQ regional plans which they say should be addressed in the latest version (Property Council of Australia, 2016). First, they claim that many planning schemes prepared by local governments do not properly reflect the intent of the regional plans. This criticism is almost entirely based on their perception that local planning schemes have not released sufficient greenfield land for new residential development, or have been insufficiently accommodating in their assessment of development proposals within the urban footprint. There is, however, little empirical evidence to support this claim (Gurran, Gilbert and Phibbs, 2013) which continues to be part of the litany of the PCA. Second, and more tellingly, they claim that there has been a failure to integrate other environmental plans and policies produced by both State and local governments in the region with the SEQ regional plans. This is part of a more widespread perception of what is often referred to as a lack of 'joined up government'. A recent review of the integration of spatial and sectoral strategies in Queensland (James and Burton, 2016) found some evidence to support this criticism, with many plans prepared by Queensland government departments and agencies having little or no explicit connection with each other, although the integration of spatial planning and infrastructure investment was more evident than in other fields. The third criticism is a lack of attention paid to the detail of how and where new jobs will be created in the region. It is certainly the case that state governments of different political persuasions have increasingly put economic growth and job creation at the heart of their broader political programs

And while there are more specific policy measures, including R\&D support schemes and employment incentives, one of the leading policy measures is the designation of State Development Areas in which planning regimes are supportive of growth and infrastructure investment is focussed. The nine current SDAs are dominated by mining and related activities, a sector that employs only 2.7 per cent of the workforce and is moving into a period of employment decline.

Overall, while the institutional arrangements of intergovernmental collaboration are well established and can reasonably be expected to continue to work satisfactorily into the future, there remains a legitimate ongoing concern with the translation of the regional strategy into 
local plans with the capacity to deliver local outcomes. This is, of course, a wider problem of planning that will be returned to in the concluding section.

\section{Conclusion}

The most significant feature of metropolitan planning for South East Queensland is that it has existed and endured for almost fifty years and helped manage the growth of this consistently fast growing region. Few other metropolitan regions in Australia have enjoyed such a consistent regional planning framework, perhaps because of its support from a strategic partnership of the state government and a relatively small group of local governments, albeit a partnership has shifted from a voluntary to a statutory basis, and it is now almost impossible to imagine that regional planning in SEQ will not continue in one form or another.

The various iterations of the SEQRP have not of course been immune from criticism, often conflicting and contradictory. For example, the latest version has been criticised on the one hand for failing to take sufficient account of the changing circumstances caused by climate change and past environmental degradation and not adequately protecting greenspaces and other ecosystems, and on the other hand for its continuing reluctance to release sufficient greenfield land that would increase the affordability of new residential developments. There is also an ongoing debate about the capacity of multi-faceted regional plans such as this to serve as a useful vehicle for integrating an array of sectoral plans and strategies. They do offer the opportunity of integration through a place-based focus, but also run the risk of becoming overburdened with policies that have no clear spatial dimension.

Perhaps the greatest threat to regional planning in SEQ lies in the political arena. The next state election must be held before January 2018, but might be held in the first half of 2017 and it is possible that Pauline Hanson's right-wing libertarian One Nation Party will win sufficient seats to hold the balance of power in the next parliament. While there has been a high degree of cross-party consensus on the case for regional planning in SEQ and for much of the policy substance of successive plans, it is much more difficult to anticipate or predict the stance of One Nation on matters such as the need to accommodate a growing population through urban consolidation, environmental protection and 'smart growth'.

Finally, regional plans like plans for any other spatial scale continue to confront the challenge of being able to regulate and manage but not to create growth. There will be parts of some regions, although few in SEQ, where the planning challenge is how to cope with inexorable economic and population decline, but mainly the task is to regulate growth in such a way as to not stifle it.

Regional and indeed local growth management strategies such as the SEQRP must create an environment in which growth is encouraged but then regulated in ways that are widely accepted as reasonable and sensible. It is not always easy to strike an appropriate balance between encouragement and regulation with the long term consequences of not doing so including substantial loss of amenity and quality of life on the one hand and the emergence of a low wage, low growth economy on the other with its attendant fiscal challenges for governments at all levels. The goals of triple (or even quadruple) bottom line sustainable development continue to underpin many regional and metropolitan planning strategies, including in SEQ, but their comprehensive achievement remains as elusive as ever. 


\section{References}

Abbott, J. (2009) Planning for Complex Metropolitan Regions A Better Future or a More Certain One? Journal of Planning Education and Research, 28(4), pp. 503-517.

Abbott, J. (2012) Collaborative governance and metropolitan planning in South East Queensland - 1990-2010: From a voluntary to statutory model, Sydney: Australian Centre of Excellence for Local Government, University of Technology Sydney.

Bell, M., Charles-Edwards, E., Wilson, T. and Cooper, J. (2010) Demographic futures for South East Queensland, Australian Planner, 47 (3), pp. 126-134.

Burton, P. (2010) Growing pains: the challenges of planning for growth in South East Queensland, Australian Planner, 47 (3), pp. 118-125.

Coffee, N., Lange, J. and Baker, E. (2016) Visualising 30 Years of Major Population Density Change in Australia's Major Capital Cities, Australian Geographer, 47 (4), pp. 511-525.

Department of Infrastructure and Planning (DIP) (2009a) South East Queensland Regional Plan 2009-31, Brisbane: The State of Queensland. Available at: http://www.dilgp.qld.gov.au/resources/plan/seq/regional-plan-2009/seq-regional-plan2009.pdf.

Department of Infrastructure and Planning (DIP) (2009b) South East Queensland Infrastructure Plan and Program, 2009-2026. Brisbane: The State of Queensland. Available at: https://www.cabinet.qld.gov.au/documents/2009/Jun/SEQIPP\%20200926/Attachments/seqipp.pdf.

Department of Infrastructure, Local Government and Planning (2016a) State Infrastructure Plan, Brisbane: DILGP.

Department of Infrastructure, Local Government and Planning (2016b) Shaping SEQ: Draft South East Queensland Regional Plan, Brisbane: DILGP.

Department of Local Government and Planning (2002) South East Queensland Performance Monitoring Report 2001. Brisbane: DLGP.

Department of Transport and Main Roads (DTMR) (2012) Travel in south-east Queensland: An analysis of travel data from 1992 to 2009, Brisbane: DTMR.

Dodson, J. (2009) The 'Infrastructure Turn' in Australian Metropolitan Spatial Planning. International Planning Studies 14(2), pp.109-123.

Gleeson, B. and Steele, W. (2009) The Bellwether Zone? Planning and Infrastructure in South-East Queensland. Paper to the $4^{\text {th }}$ State of Australian Cities Conference, Perth, 24-27 November. Available at: http://apo.org.au/node/60117.

Gleeson, B. and Steele, W. (2010) Afterword: The state of exception, in Gleeson, B. and Steele, W. (eds.) A climate for growth, Brisbane: University of Queensland Press, pp.277285.

Gleeson, B., Dodson, J., and Spiller, M. (2012) Governance, metropolitan planning and citybuilding: the case for reform, in Tomlinson, R. (ed) Australia's Unintended Cities: The 
Impact of Housing on Urban Development, Clayton South, VIC: CSIRO Publishing, pp. 117133.

Guhathakurta, S. and Stimson, R. (2007) What is driving the growth of new 'Sunbelt' metropolises? Quality of life and urban regimes in Greater Phoenix and Brisbane-South East Queensland Region, International Planning Studies, 12 (2), pp. 129-152.

Gurran, N., Gilbert, C., and Phibbs, P. (2013). Planning and the Housing Market: Measuring Regulatory Difference and Implications for Explaining Supply and Affordability Trends. Paper to the 7th Australasian Housing Researchers' Conference, Fremantle, 6th -8 th February.

Hajkowicz, S., Cook, H. and Littleboy, A. (2012) Our Future World: Global megatrends that will change the way we live, Brisbane: CSIRO.

Hamnett, S. and Freestone, R. (eds.) (2000) The Australian Metropolis: A Planning History. Sydney: Allen and Unwin.

Hamnett, S. and Freestone, R. (2016) The Australian Metropolis 2000-2015. Proceedings of the 17th International Planning History Society Conference Delft, The Netherlands. 17-21 July. Available at: http://journals.library.tudelft.nl/index.php/iphs/article/view/1324 .

Ireland, J.(2006) Local Growth Management Strategies and Structure Plans, Brisbane: Hopgood Ganim Lawyers. Available at:

http://www.hopgoodganim.com.au/icms_docs/135818_HG_Paper_SEQ_Regional_Plan_200 5-2026_-_Growth_Management_Structure_Plans_-_Nov_2006.pdf.

James, B. and Burton, P. (2016) Review of Queensland State Government Plans and Strategies, unpublished report available on request from Griffith University, Cities Research Institute.

Margerum, R.D. (2002) Evaluating Collaborative Planning, Journal of the American Planning Association, 68 (2), pp. 179-193

Matthews, T., Lo, A. and Byrne, J. (2015) Reconceptualizing green infrastructure for climate change adaptation: Barriers to adoption and drivers for uptake by spatial planners, Landscape and Urban Planning, 138, pp. 155-163.

Minnery, J. and Low Choy, D.(2010) Early innovations and false starts, in Gleeson, B. and Steele, W. (eds.) A climate for growth, Brisbane: University of Queensland Press, pp.23-38.

Newman, C. (2012) Campbell Newman makes big pitch to business, $A B C / P M$ transcript, first broadcast 25 September, Available at:

http://www.abc.net.au/pm/content/2012/s3597684.htm.

Office of Urban Management (2005a) South East Queensland Infrastructure Plan and Program 2005-2026. Brisbane: Queensland Government.

Office of Urban Management (2005b) South East Queensland Regional Plan 2005-2026. Brisbane: Queensland Government.

Property Council of Australia (2016) Making the plan a reality: South East Queensland Regional Plan 2016 - The industry perspective on achieving best practice regional planning, Brisbane: Property Council of Australia. Available at: 
https://www.propertycouncil.com.au/Web/Content/News/QLD/2016/Making_the_Plan_a_Re ality.aspx.

Queensland Government (2014) The Queensland Plan, Brisbane: The State of Queensland. Queensland Government Statistician's Office (2016) Population growth highlights and trends, Queensland, 2016 edition, Brisbane: Queensland Treasury.

Regan, M., and Bajracharya, B. (2010) Integrating regional and infrastructure planning: Lessons from South East Queensland, Australia, in Yigitcanlar, T. (ed.) Sustainable urban and regional infrastructure: Technologies, applications and management. Hershey, PA: Information Science Reference, pp. 259-276.

Savery, N. (2010) Planning and growth in South East Queensland, Australian Planner, 47 (3), p. 117.

Searle, G. (2010) Too concentrated? The planned distribution of residential density in SEQ, Australian Planner, 47 (3), pp. 135-141.

Spencer, A., Gill, J. and Schmahmann, L. (2015) Urban or suburban? Examining the density of Australian cities in a global context. Paper to the 7th State of Australian Cities Conference, Gold Coast, 9-11 December. Available at: http://apo.org.au/node/63334.

Vit, M. (2016) South East Queensland Regional Plan: Letter to Stuart Moseley, DILGP, available at: http://www.udiaqld.com.au/getmedia/c464942b-8397-4e2f-8a809ea3fb063733/Letter-to-Stuart-Moseley-re-UDIA-s-SEQRP-position-28-July2016.pdf.aspx?ext=.pdf 